\title{
Enhancement of industry initiative through the Zero-energy Mass Custom Home Mission to Japan experience towards commercialisation
}

\author{
Masa Noguchi \\ MEARU, \\ Mackintosh School of Architecture, \\ The Glasgow School of Art, \\ 167 Renfrew Street, Glasgow G3 6RQ, UK \\ E-mail: m.noguchi@gsa.ac.uk
}

\begin{abstract}
In response to growing global warming issues and increasing energy prices, house-builders today are becoming keener on the delivery of zero energy sustainable homes than ever. Nevertheless, their business operation still tends to develop into routine in view of their close system mode of operation. In 2006, to stimulate the industry, knowledge transfer study visits to Japanese net zero energy cost mass custom housing manufacturers were initiated. The educational event was later called 'Zero-energy Mass Custom Home Mission to Japan' and was resumed in 2007, 2008 and 2010. Consequently, three industry participants were transformed successfully from conventional housing suppliers to early adopters of net zero energy/carbon-emission homebuilders in their local contexts. This study demonstrates the gravity of the mission's execution that was aimed at putting the theory of organisational buying behaviour into practice in order to develop a way to change the nature of the homebuilding industry towards the delivery of zero energy mass custom homes of the future.
\end{abstract}

Keywords: ZEMCH network; Zero-energy Mass Custom Homes; zero carbon emission homes; prefabrication; mass custom design; industry education; sustainable housing development; awareness enhancement; commercialisation; Japan.

Reference to this paper should be made as follows: Noguchi, M. (2011) 'Enhancement of industry initiative through the Zero-energy Mass Custom Home Mission to Japan experience towards commercialisation', Int. J. Mass Customisation, Vol. 4, Nos. 1/2, pp.106-121.

Biographical notes: Masa Noguchi is a Reader at Mackintosh School of Architecture, The Glasgow School of Art (GSA), and Co-director of Zero-energy Mass Custom Home (ZEMCH) research specialism, Mackintosh Environmental Architecture Research Unit (MEARU). He is Initiator and Coordinator of 'ZEMCH network', serving as an Academic Supervisor of a $£ 1.5$ million ZEMCH Donside Urban Village, Z-en house, and ZEMCH Prestwick projects undertaken by the industry partners in Scotland. In 2007, he also contributed to leading the architectural design of the EcoTerra ${ }^{\circledR}$ house known as Canada's first net zero-energy house built and commercialised through the Canadian federal government's EQuilibrium sustainable housing initiative. The design features have been introduced widely through the IEA SHC/ECBCS Task 40/Annex 52 programme, in which he is taking the role of the UK national contact. In 2011, he realised the world's first ZEMCH post-graduate course at GSA, while organising the ZEMCH 2012 international conference in collaboration with the network's founding partners. 


\section{Introduction}

Housing is a system of energy and environment. Homes are responsible for a great deal of carbon dioxide $\left(\mathrm{CO}_{2}\right)$ emissions that encompass the enormous impact on global warming. For instance, housing accounts for $27 \%$ of the national carbon footprint in the UK to which each dwelling unit contributes on average 3 tons $\mathrm{CO}_{2}$ per annum. How on earth can the $\mathrm{CO}_{2}$ emissions in housing be reduced or eliminated over the lifecycle? Undoubtedly, the mass production and marketing of net zero carbon emission housing is the key to resolving the societal pressure. Prior to the discussion of carbon-neutral housing, the energy use in housing needs to be reduced to low or zero levels. In essence, zero energy housing falls into two categories: self-sustainable or net. The former type is a standalone house whose operational energy relies solely on its own power generation and storage so that it is disconnected from the outside sources. The latter is the one whose energy use becomes net zero over a fixed period of time. Moreover, a house whose energy bill becomes net zero under the same conditions is termed net zero energy cost housing. The notion of zero carbon housing today is from time to time linked to that of these abovementioned homes; perchance, the performance may entail the further steps to cover $\mathrm{CO}_{2}$ emissions that derive from not only the operation but also the construction and demolition over the house's lifecycle.

In theory, homebuilders and housing manufactures are sensitive to societal needs and demands. Yet, in reality, traditional builders generally tend to follow routines in their way of doing business and cut down information search for determining whether or not to adapt unfamiliar design challenges, and innovative building materials and systems. Nonetheless, to build zero carbon mass custom homes that aim to satisfy the wants and needs of individual consumers as well as society may require the use of innovations. Then, how can such conventional house-builders and housing manufacturers be adapted to new business operations required for the delivery of zero carbon mass custom homes, whose design, production and marketing approaches may not be akin to those to which they are accustomed? In order for conventional homebuilders and housing manufacturers to grasp new business opportunities, the Zero-energy Mass Custom Home Mission to Japan knowledge transfer educational event was organised in view of the factors relating to industrial buying behaviour.

The following sections firstly review the theoretical aspects of 'organisational buying behaviour' with the aim to grasp the nature of the homebuilding industry. Secondly, the contents of the Zero-energy Mass Custom Home Mission to Japan knowledge transfer educational event organised based on the factors relating to the industrial purchase behavioural theory reviewed will be identified. Thirdly, the industry participants' response to the delivery of zero carbon mass custom homes will be reviewed so as to examine the effect of the event on industry education towards the commercialisation.

\section{Industrial buying decision-making factors}

Housing development involves the purchase of products and services. Hence, homebuilders can be considered as industrial (or organisational) buying decision-makers who determine whether or not to subcontract out to familiar or unfamiliar sub-contractors (i.e., suppliers) who actually execute housing projects initiated by the builders. Webster and Wind (1972) defined 'organisational buying behaviour' as: “the decision-making 
process by which formal organisations establish the need for purchased products and services, and identify, evaluate, and choose among alternative brands and suppliers”. The term 'decision-making' used in this definition includes information acquisition and processing activities, as well as the development of goals and other multiple criteria to be used in choosing amongst the alternatives. The organisational buying process is complex and decisions are influenced essentially by task- and non-task-related variables. 'Task-oriented' organisational buying decision models include those that emphasise task-related variables. Minimum price and lowest total cost models may well exemplify the task-oriented models with regard to monetary considerations. 'Non-task-oriented' models are those that attempt to explain organisational buying behaviour based on a set of variables which have no direct bearing on the specific problem to be solved by the buying task. Non-task-oriented models generally concern the emotional factors influencing organisational buying behaviour, thus disregarding the rational (or economic) factors as aforesaid. The task-oriented models may be most useful for investment justification; however, these models may suffer the disadvantages of incompleteness due to the absence of non task variables - e.g., 'perceived risk' (Schiffman and Kanuk, 1999). In general, the major types of risk that buyers somehow perceive when making a buying decision include performance risk, financial risk, psychosocial risk, and time risk.

Organisational buyers may adopt several strategies for reducing the amount of perceived risk. Firstly, the buyers may simply avoid a decision. Secondly, they may remain loyal to 'in' suppliers to maintain their 'routine' purchase. Thirdly, they may extensively gather and evaluate additional information in the search of new products or services. Fourthly, they may do business with well-known, reputable, established suppliers and this also reflects 'brand loyalty' - the term is used to describe consumers' consistent preference and/or purchase of the same brand in a specific product or service category. Webster and Wind (1972) introduced a unique approach to avoiding uncertainty in the course of the organisational buying action (i.e., 'split orders') and indicated that "Another strategy used by organisational buyers to reduce risk is to split orders between two or more vendors, although single sourcing (especially from well-known suppliers) was found to be more common practice...” This approach may help buying organisations venture to apply more innovative products that meet their demand, whilst they can reduce risk by splitting the orders between two or more suppliers. In this case, buyers may be able to choose 'in' and 'out' suppliers not only for conventional products, but also for innovative products. The weight given to each of the suppliers for their products or services that will be purchased may vary according to the buying organisations' needs and demands for them. A 'Design Charrette' approach being applied nowadays for the delivery of low to zero energy sustainable homes, which requires interdisciplinary collaborations on the design and construction decision-making (and problem-solving) activities involved, may somewhat reflect the means of alleviating organisational buying uncertainty (Onyango and Noguchi, 2009).

The amount of uncertainty surrounding the purchase of a new product or service may be reduced through a series of problem-solving activities - the term 'problem solving' used in the field of consumer behaviour implies a general approach to understanding consumer decision making and it focuses on consumers' cognitive representation of the decision as a problem (Onkvisit and Shaw, 1994). Important aspects of the problem representation include consumers' end goals, sub-goals and relevant knowledge. Consumers construct a decision plan by integrating their knowledge within the constraints of problem representation (Peter and Olson, 1996). However, the type of 
problem solving adopted depends on the task at hand. In short, it is classified into two buying situations: programmed and non-programmed (Figure 1).

Figure 1 Classification of problem solving

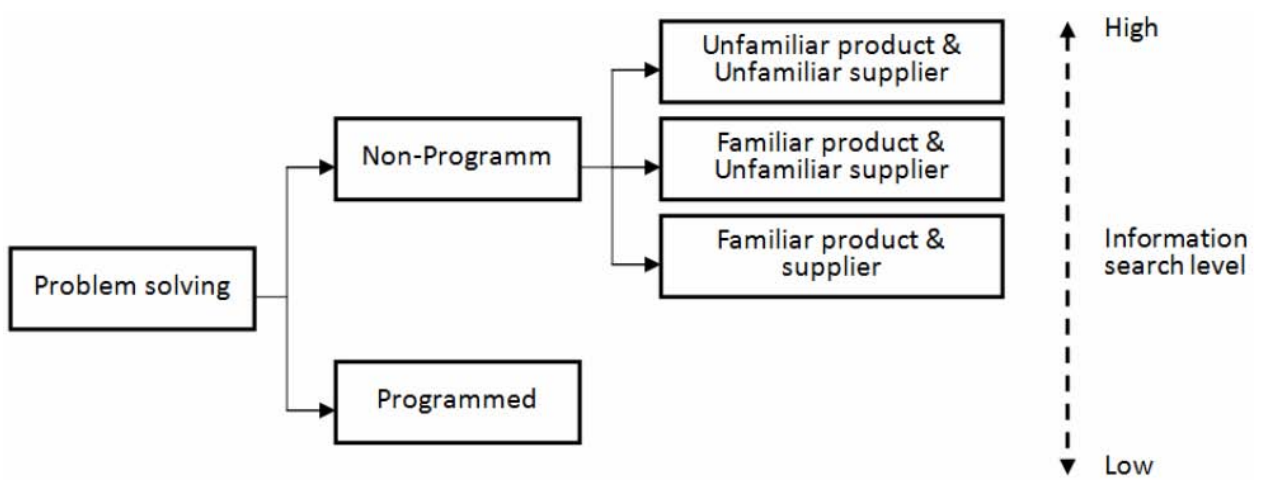

Source: Noguchi (2008a)

A 'programmed' decision reflects a habitual (or routine) purchase, and it may lead almost immediately to a purchase, whilst a 'non-programmed' decision may require more time (which can be also considered as a cost relating to the search) for the acquisition and processing of information on a product to be purchased (Blythe, 1997). Information search usually comes from an internal search from memory and an external search from outside sources. The extent of the external search for information depends on a range of factors that are connected with the buyer's situation, the value and availability of the information, the nature of the decision being contemplated, and the nature of the individual.

\section{Zero-energy Mass Custom Home Mission to Japan}

There is a tendency for house-builders to rarely adopt or buy new products and services that to some extent interrupt their business operation that is often based on routine. However, the routine has been streamlined to a point at which homebuilders achieve great efficiency of their activities. Roberts (1970) emphasises that 'working drawings' are extremely simplified because craftsmen know how to carry out their task, based on traditional construction techniques and housing 'specifications' are also brief, because the designers know that craftsmen know how to fit materials together. In general, homebuilders tend to restrict their information search to the programmed decision, since the search for information for non-programmed decisions take too much time, money and effort (Noguchi, 2008a). Therefore, to open the gate for conventional homebuilders and housing manufacturers to consider the future production of their own net zero energy/carbon sustainable houses, the 'Zero-energy Mass Custom Home Mission to Japan' was initiated by the author. In Japan, a total of 1,093,485 houses were newly built in 2008 and amongst them, 154,271 homes, or 14.1\%, were estimated to be prefabricated (JPA, 2010). Moreover, the housing manufacturers have been successful in commercialising their industrialised houses that are often equipped with renewable energy technologies, e.g., photovoltaic (PV) power generation and air-source hear pump 
systems, as standard features rather than options (Noguchi and Collins, 2008). This quality-oriented production approach reflects their high 'cost-performance' marketing strategy (Noguchi, 2003). Between 1994 and 2003, the number of domestic PV installations in Japan drastically increased from 539 to 52,863 houses. To alleviate the eccentric appearance of their contemporary PV solar homes, Japanese manufacturers tend to well integrate the cells into the roofing and façade materials (Figure 2).

Figure 2 'Wa no Nagomi’ zero energy cost house in Japan (see online version for colours)

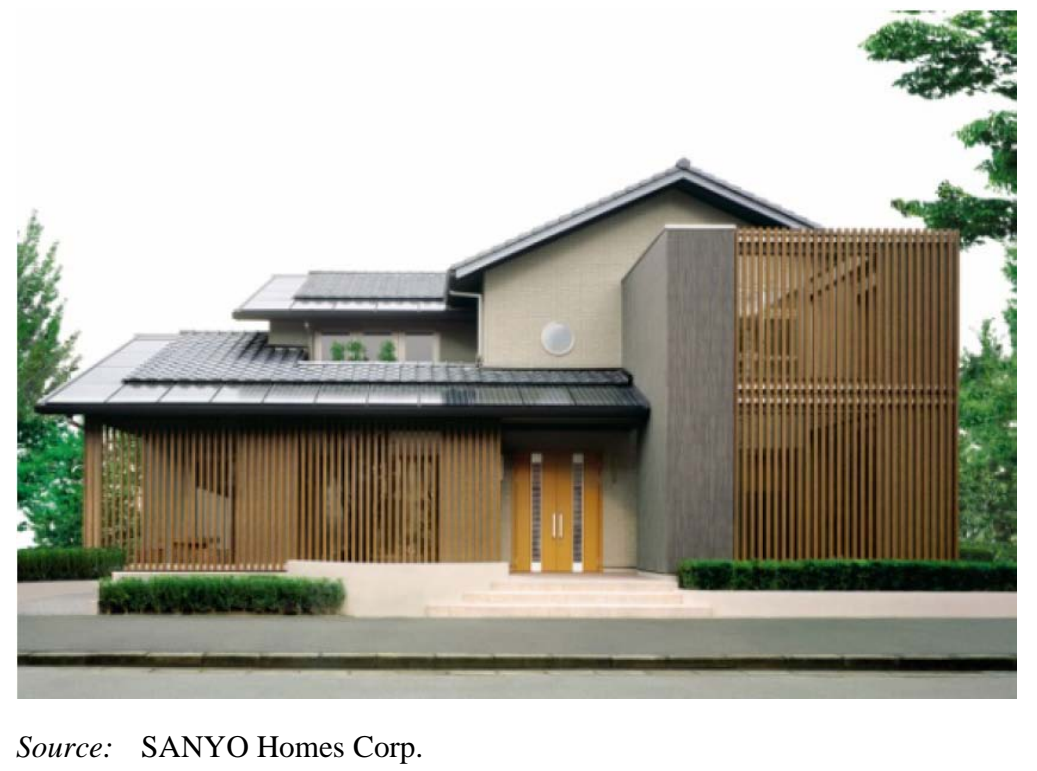

In 2005, CANMET Energy Technology Centre (called 'CanmetENERGY' today) Varennes, Natural Resources Canada, supported the author of this study and Prof. Roger-Bruno Richard, the University of Montreal, for the organisation of 'Japan Solar Photovoltaic Manufactured Housing Technical Mission 2006’. The knowledge transfer educational event was held from 20 to 23 February, 2006, with the aim to provide Canadian homebuilders, housing manufacturers, building component suppliers, architects, academics and government officers with opportunities to explore not only the state-of-the-art production facilities of the then four leading net zero energy cost housing manufacturers in Japan, i.e., Sekisui Chemical Co. Ltd., Misawa Homes Co. Ltd., PanaHome Corp., and SANYO Homes Corp., but also a sales centre that displays a variety of Japanese manufacturers' housing prototypes (Richard and Noguchi 2006). Based on the past experience, from 3 to 5 September, 2007, the educational event was reorganised by MEARU, Mackintosh School of Architecture, The Glasgow School of Art, in collaboration with the Centre for the Built Environment in the UK. Then it was renamed to 'Zero-carbon Mass Custom Home Mission to Japan' and added a visit to Sekisui House Ltd. which had been committed to the development of a zero carbon emission house towards the future exhibition during the G8 Hokkaido Toyako Summit that was expected to be held in the following year. In 2008, the title was again changed to 'Zero-energy Mass Custom Home Mission to Japan' and was held from 10 to 12 September. In 2010, the mission was organised as one of the 'Renewable Energy 2010' international conference's related events held from 23 to 25 June. In addition to the 
company visits, a post-mission strategic 'Zero-energy Housing' workshop was also executed within the conference programme in which 20 delegates from Australia, Brazil, Canada, Italy, Korea, Portugal, Sweden, UK and USA were invited as panellists to report the mission outcomes and discuss issues around the delivery of net zero energy/carbon mass custom homes today. The workshop helped establish a forum of interactive discussion on the design, production and marketing approaches and solidify diverse individual expertise and experience into universal knowledge.

\section{Company profiles}

During the Zero-energy Mass Custom Home Mission to Japan event, the participants were given opportunities to scrutinise innovative design, production, and marketing techniques being applied to the commercialisation of low to zero energy sustainable homes in Japan. In addition to the five mass custom housing manufacturers, as described above, the 2010 mission also extended the scope and arranged another visit to the showroom of a building material and sanitary system manufacturer. In order to highlight the distinguishing features of all manufacturers visited during the event, the company profiles will be summarised below.

- INAX Corp.: Since 1924, INAX has pioneered a number of industry innovations including the first Japanese shower toilet and the world's first self-powered, automatic water faucet. The company is based in Tokyo, Japan, employing 15,861 workers (as of March 31, 2009). INAX manufactures and supplies building materials, tiling and sanitary fixtures applied for residential, commercial and public buildings and facilities. The company is considered as a practitioner of 'mass customisation' when designing their modularised bathroom unit in compliance with customers' choices of the standard building components given. Miniature bathroom models accompanied by a set of the material options are utilised to mass-customise the unit with the aim to accommodate the user demands, requirements and expectations (Figure 3). Most clients visit their showroom a few times to understand the value of product quality and decide a particular bathroom style available for their further design arrangements. However, once the style is determined, the bathroom unit design can be completed within 2 hours using the relevant mass-customisable miniature model.

- Sekisui Chemical Co. Ltd.: The company is also well known as 'Sekisui Heim' that derives from the name of Japan's first modular house that they built in 1971. Sekisui Chemical is aiming to develop business that focuses on the production of high performance and value-added housing products where their modular construction system technologies are brought into effect. In general, modular housing systems ensure a high level of in-factory completeness of housing components. The company claims that nearly $80 \%$ of housing components used for building a house can be assembled at their factory. Today, Sekisui Heim possesses eight factories nationwide which have the capacity for producing wood- and/or steel-frame modular homes through their highly mechanised assembly lines (Figure 4). Moreover, given the cumulative sales of over 85,000 solar homes to date, the company is also recognised widely as the largest modular manufacturer of net zero utility cost housing in Japan. 
Figure 3 Miniature bathroom unit model for ceramic wall tile and bathtub selections (see online version for colours)

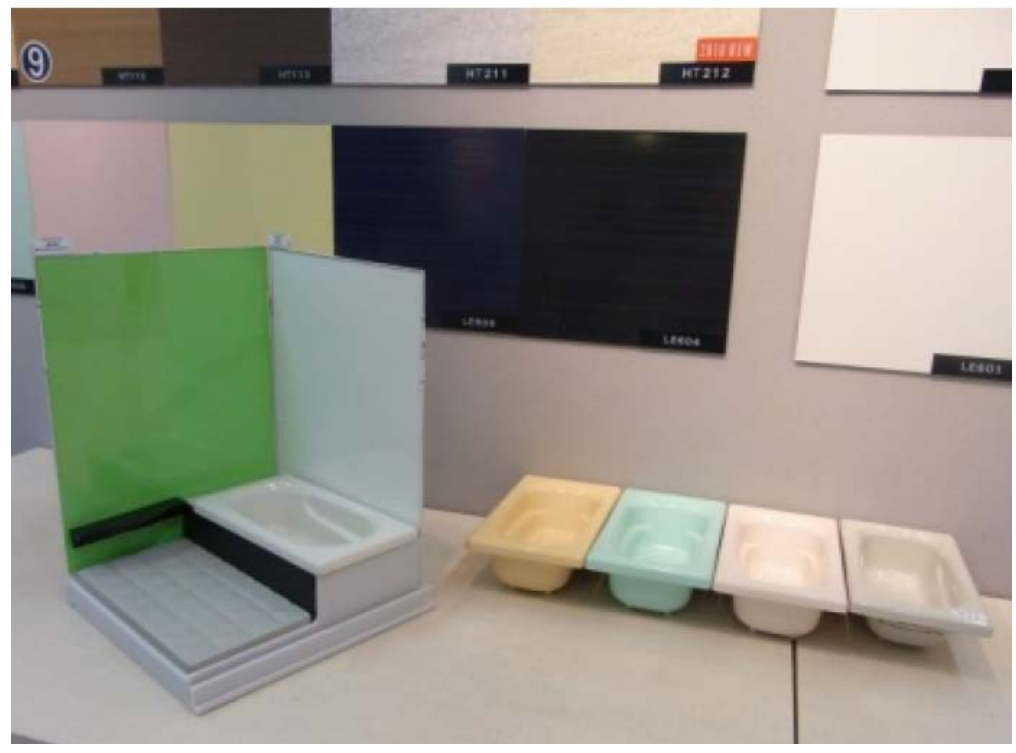

Source: INAX Corp.

Figure 4 Sekisui Heim production line (see online version for colours)

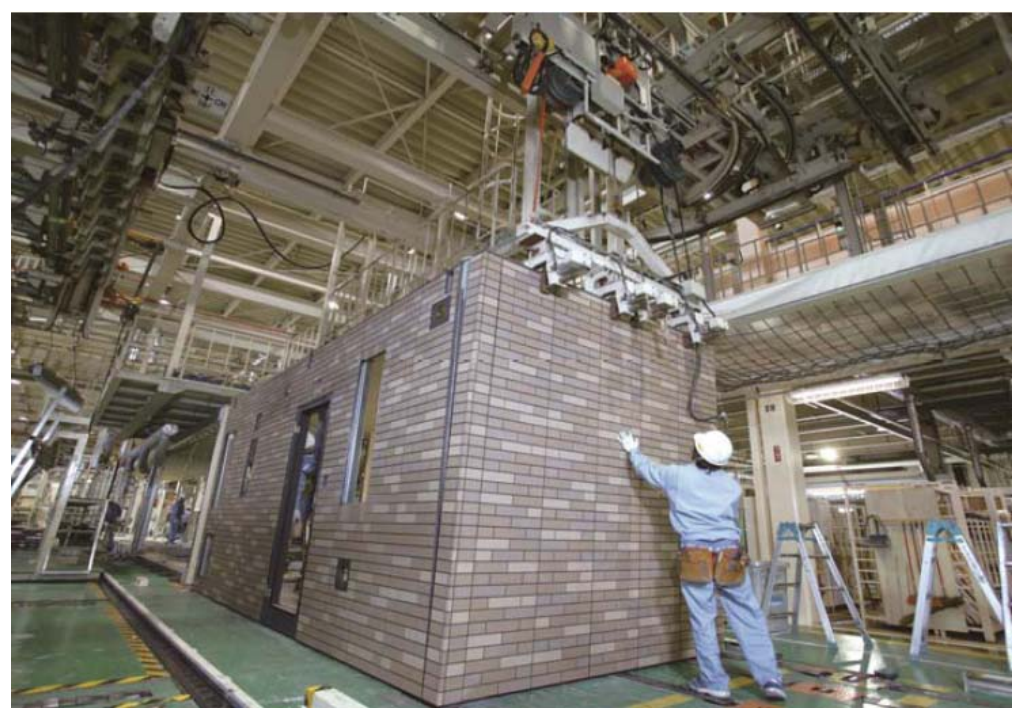

Source: Sekisui Chemical CO. Ltd.

- $\quad$ Misawa Homes Co. Ltd.: The company was founded in 1967, headquartered in Tokyo, Japan. Misawa Homes, together with its subsidiaries, engages in the development, construction, and sale of prefabricated mass custom homes and housing materials. Their house is also constructed based on three-dimensional modules consisting of rigid steel frames. Yet, their homes are characterised by the 
use of large-sized non-structural 'pre-cast autoclaved lightweight concrete’ (PALC) panels that the company produces (Figure 5). Misawa Homes started business operations upon acquisition of the housing industry's first certification from the then Ministry of Construction in 1962. The company spread a 'Home Core' design concept by building the demonstration homes in Abu Dhabi, UAE in 1968.

Afterwards, Misawa Homes put 1-million JPY Home Core houses on the local market in 1969 and the concept was well exhibited at Expo '70 in Osaka. In 1980, the company commenced with research on the development of its own zero energy housing prototype and in 1998, it successfully commercialised Japan’s first zero energy homes.

Figure 5 PALC panels (see online version for colours)

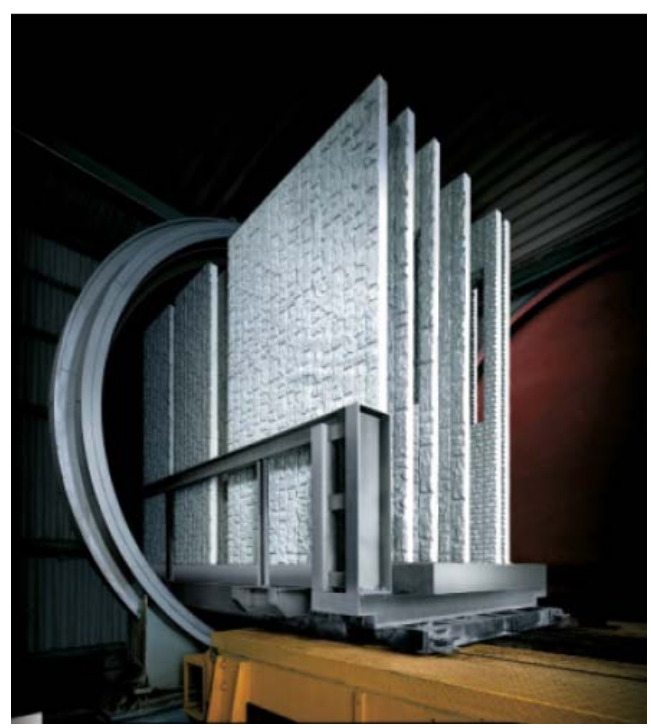

Source: Misawa Homes Co. Ltd.

- PanaHome Corp.: Since 1963, PanaHome, formerly called 'National House Industrial Co. Ltd.’, has been operating as a housing company within Panasonic Group. Yet, the group's housing business itself actually dates back to the introduction of its first house prototype called 'Matsushita Type-One Housing Units' in 1961. Then, the Koto Plant (present Head Plant) also opened in Shiga Prefecture. Today, PanaHome produces steel-frame panels applied to their industrialised mass custom homes through highly automated production lines. In line with their state-of-the-art automation system, the company has also been at the forefront of solar community developments. In fact, the PanaHome City Seishin Minami housing estate in Hyogo Prefecture was selected as one of 100 excellent regional projects that introduced new types of energy hosted by the Ministry of Economy, Trade and Industry, and the New Energy and Industrial Technology Development Organization (Figure 6). Afterwards, their proposal was also adopted in a scheme, which was led by the Ministry of Land, Infrastructure, Transport and Tourism, and entitled 'Initiative Model Project for Developing Long-Life Houses'. 
Figure 6 PanaHome City Seishin Minami housing estate in Hyogo Prefecture (see online version for colours)

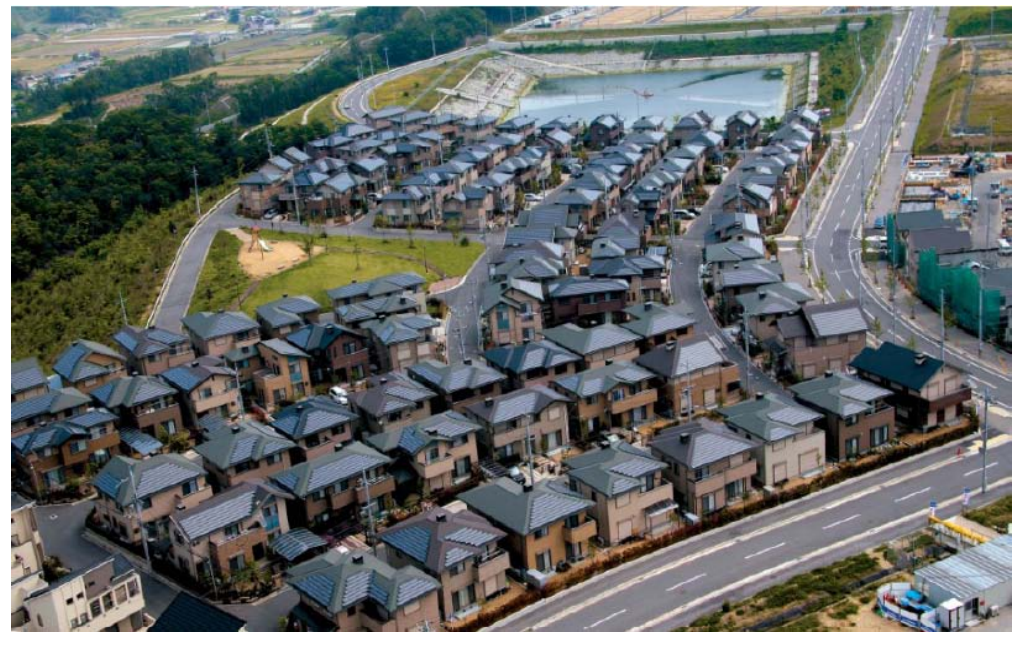

Source: PanaHome Corp.

- SANYO Homes Corp.: The forerunner of SANYO Homes Corp. is 'Kubota House Co. Ltd.' which was established in 1969 and won the first place for 'The 1st Pilothouse Technique Invention Competition' held in 1972 by the then Ministry of Construction in Japan. In 2002, the company was renamed to 'SANYO Homes' as it became owned by SANYO Electric Co. Ltd. Today, SANYO Homes emphasises that housing should be gentle to people and the earth, stemming from the company's business concept of an 'Eco \& Safety' life that aims to enhance their housing performance as to local power generation, energy-efficiency, and earthquake resistance and emergency measures. In 2004, SANYO Homes received a 'Good Design' award with their housing prototype called 'Logia-Type E' which had a simple cubical exterior appearance designed based on a minimalism concept for space use efficiency. The company is thriving in their mass custom homes' architectural integration with SANYO HIT solar cells that have the world's highest energy conversion efficiency of 23\% (Figure 2). The company also introduces solar water heating panels to their homes equipped with an air-source heat pump, which aims to control and secure the supply of domestic hot water according to weather conditions.

- Sekisui House Ltd.: In 1960, the company incorporated with the capital stock of 100 million JPY, stemming from the housing division of Sekisui Chemical Co. Ltd. Today, Sekisui House is recognised as the largest housing manufacturer in Japan given the cumulative sales of 2,001,722 homes estimated as of 31 January 2010. The company is committed to taking the initiative for the development of zero carbon emission housing based on the company's 'Action Plan 20' that aimed to introduce a variety of energy-efficient housing measures (Ishida, 2008). In conjunction with the G8 Hokkaido Toyako Summit held from 7 to 9 July, 2008, Sekisui House announced their so-called 'Zero Emission House'. The house was a single-storey steel structure prefabricated house with a total floor area of approximately $200 \mathrm{~m}^{2}$, featured particularly by a $14.5 \mathrm{kWp}$ capacity PV power generation system, energy efficient 
lighting, a household fuel cell, and energy saving domestic appliances. Moreover, in order to assist clients in understanding the value of their products, Sekisui House opens the home amenities experience studio, called 'Nattoku Kobo', to the general public. The studio provides a variety of information on housing functions and performances such as lifetime barrier free design, home security, earthquake and typhoon resistance, energy and space use efficiency, and local power generation (Figure 7).

Figure 7 'Nattoku Kobo’ home amenities experience studio (see online version for colours)

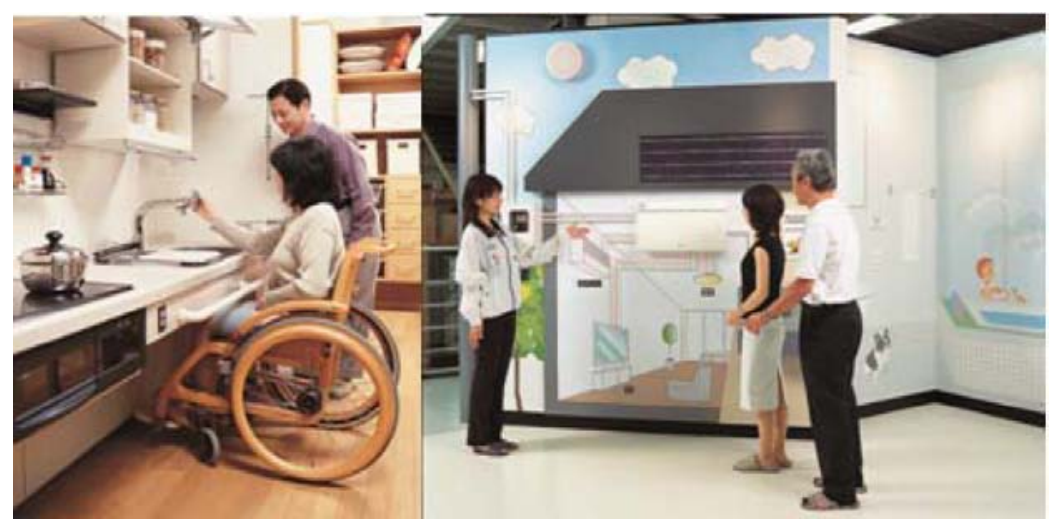

Source: Sekisui House, Ltd.

The housing manufacturers' communication approaches derived from their cultural context, in which 'customer satisfaction' is of utmost concern. Prior to entering into a contract with their clients, the manufacturers offer an extensive amount of information in order to motivate consumers to learn more about the company's products and services during the buying decision-making process. Today, in response to the market demands for design customisability of housing and the societal needs for sustainable development, Japanese manufacturers tend to produce high cost-performance homes (Noguchi and Collins, 2008). In order to enhance clients' motivation for purchase of high cost-performance housing, the manufacturers have been practicing three principal communication approaches to dealing with potential homebuyers (Noguchi and Friedman, 2002):

1 advertisement

2 education

3 value assurance.

Their communication approaches applied to each stage of their marketing efforts are proven to be influential in the enhancement of customer satisfaction. The JPA (2008) unveiled an annual survey of consumer preferences in the purchase of industrialised housing in Japan. The survey indicates that the perceived high quality of industrialised housing was the utmost significant factor that attracts potential buyers (Table 1). In fact, $22 \%$ of the purchasers that replied to this survey said that their primary factor influencing their buying decision was the 'reliability' of the large-scale housing company, which somewhat reflects the 'brand name' effect on the sales. $18 \%$ of the buyers preferred to 
live in an industrialised house due to the higher levels of housing performance. Ranking next to them, $17 \%$ of the homeowners responded that they purchased an industrialised house because it was designed to be earthquake-resistant. $15 \%$ of the buyers preferred the factory-built home since they were well convinced of the sales staff's explanation as to the product features and the company's services offered to their clients before and after occupancy. These results suggest that homebuyers in Japan tend to consider the quality of housing to be the top priority, whilst the selling price is less of a consideration. Only 2\% of the buyers regarded the total price of industrialised housing as relatively low. In other words, Japanese consumers venture to purchase an innovative industrialised house, whose price is higher than the site-built one, if convinced of the superior housing quality.

Table 1 Buyers' motivation to purchase industrialised housing in Japan

\begin{tabular}{lc}
\hline Motivation factors selected & Year 2008 \\
\hline Reliability of the large-scale company & $22 \%$ \\
Superior product quality and performance & 18 \\
Earthquake resistance & 17 \\
Convinced by the sales persons' explanation & 15 \\
Good post-purchase services & 2 \\
Good design & 4 \\
Customisation according to needs and demands & 5 \\
Reliable safety measures & 0 \\
Short construction time & 2 \\
Wide variety of equipment selections & 1 \\
Confirmed by visiting housing exhibitions & 1 \\
Consideration of environmental issues & 1 \\
Recommendation from acquaintance & 3 \\
Relatively low price & 2 \\
\hline
\end{tabular}

Source: Noguchi and Collins (2008)

Japanese housing manufacturers produce marketable and reproducible low to zero energy mass custom homes that aim to meet the wants and needs of individuals as well as society. The 'mass custom design' approach may theoretically achieve a high level of standardisation of housing components that homebuyers can directly select in planning their new home, whilst the user choices of the mass-producible standard components paradoxically increases a level of design customisability (Noguchi and Hadjri, 2009). Thus, it contributes to reducing design and production costs by achieving the economies of scope, whilst helping to customise a house in consideration of the buyer's economic constraint (Noguchi and Hernández, 2005). Yet, Japanese housing manufacturers may use the money, which could be saved from lowering design and production costs through mass customisation, for equipping homes with luxurious standard equipment; thus, this, in turn, upgrades housing quality and distinguishes their products from conventionally built houses. In fact, the manufacturers today tend to install a variety of amenities including PV and air-source heat pump systems as standard features rather than options and emphasise that they have been producing better-quality homes for about the same price as conventional ones (Noguchi and Collins, 2008). 


\section{Post-mission industry response}

As per the post-mission feedback, most delegates who participated in the past 'Zero-energy Mass Custom Home Mission to Japan' educational events expressed their positive impression on Japanese manufacturers' systematic and innovative way of commercialising low to zero energy prefabricated homes (Richard and Noguchi, 2006). A number of the participants admit that Japanese housing manufacturers, which they visited, were all large-scale enterprises and might be able to invest heavily in developing their own design, production and marketing approaches to the industrialised homes equipped with luxurious renewable energy technologies. The feedback led to an argument that small- or medium-sized homebuilders and housing manufacturers, such as mission industry delegates, may hardly apply Japanese manufacturers' commercialisation approach to low to zero energy mass custom homes without scaling down the extent. Notwithstanding the remaining concern over the applicability of costly renewable technologies, whose application may somewhat necessitate the change of their routine business operation, three companies (i.e., Alouette Homes, Tenants First Housing Co-operative, and ROBERTRYAN Homes) who attended the knowledge transfer educational event held in 2006, 2007 and 2008 raised their motivation and took the initiative to actually produce and commercialise zero energy/carbon mass custom homes in their local contexts.

The following sections will describe the companies' challenges, attempts and achievements after their experience of the past Zero-energy Mass Custom Home Mission to Japan organised particularly in consideration of the industrial buying behaviour. Perceived risks associated with the industrial purchase of unfamiliar products and services may be mitigated by observing the successful implementations accompanied by the early adopters' problem solving buying decisions.

\subsection{Alouette Homes}

Alouette Homes is a panelised and modular housing manufacturer based in Quebec, Canada. The company attended the first mission held in 2006. Immediately after the factory visits in Japan, the company considered the actual production of PV solar housing in Canadian climates. In fact, receiving support from external zero energy housing experts including the author of this study as the housing design lead and Prof. Andreas Athienitis as the engineering lead, the manufacturer developed its own near net zero energy house prototype, later called 'ÉcoTerra house' (Noguchi, 2008b). The house is a single detached home built on a 1.1 hectare rural lot of a new mass housing development in Eastman, Quebec (Figure 8).

The floor area of this house is $141 \mathrm{~m}^{2}$ and two bedrooms are located on the first floor and semiprivate spaces, such as a kitchen, dining room, and sunspace family room/lounge, are on the ground floor. A semi-basement was introduced to this project, serving as a multifunctional space and machine room. The total heated floor area of the house was estimated at $234 \mathrm{~m}^{2}$ and the heated volume at $671 \mathrm{~m}^{2}$ including the basement. The house was constructed by making use of Alouette Homes' pre-engineered modular housing system that helped eliminate or reduce on-site construction nuisances, such as bad weather, theft and vandalism. A closed garage is located on the north side of the house being attached to the façade; thus, it somewhat functions as an air buffer space that reduces the fabric heat loss. The south wall is fitted with generous south-glazing. The 
window area of the south, west, east and north walls were estimated at $20.90 \mathrm{~m}^{2}, 5.20 \mathrm{~m}^{2}$, $6.67 \mathrm{~m}^{2}$ and $0.65 \mathrm{~m}^{2}$, respectively. The south-glazing to floor ratio is $9.1 \%$. The glazing areas allocated to the exterior walls of this house were designed to ensure the comfortable level of natural day-lighting and reduce the total amount of electricity required for artificial lighting. In the ÉcoTerra house, a $3 \mathrm{kWp}$ building integrated photovoltaic thermal (BIPV/T) system was installed. The PV array of the BIPV/T system is comprised of 22 amorphous silicon $136 \mathrm{~W}$ laminates placed on the $55 \mathrm{~m}^{2}(5.8 \mathrm{~m} \times 9.5 \mathrm{~m})$ south-facing metal rooftop. The potential annual electricity production was estimated initially at approximately 3,420 kWh when the roof faces is sloped at $30.3^{\circ}$. The air under the PV panels is heated by solar radiation, drawn into the lower portion of the house from the roof ridge ducted. The BIPV/T system introduced to the ÉcoTerra house contributes to the drastic reduction of energy consumption for heating the space and water in addition to the alleviation or elimination of an electric clothes tumble dryer use. With due consideration of the utilisation of the advanced renewable energy technologies combined with passive solar techniques applied to the ÉcoTerra house, the annual space energy consumption would become as low as $1,130 \mathrm{kWh}$. The electricity used for domestic hot water reduced from $3,353 \mathrm{kWh}$ to $553 \mathrm{kWh}$ as a result of the contributions of the heat pump desuperheater, BIPV/T system and drain-water heat recovery unit. As for the energy consumption of indoor lighting, appliances and exterior use electrical equipment, it was decreased from 3,975 $\mathrm{kWh}$ to $3,275 \mathrm{kWh}$ with the reduced energy load for an electric dryer. Subtracting the expected PV electricity generation of 3,420 kWh from the sum of these figures, the annual energy consumption of the ÉcoTerra house can be re-estimated at 2,155 $\mathrm{kWh}$. However, this excludes the magnitude of user behaviour.

Figure 8 The ÉcoTerra house, Alouette Homes (see online version for colours)

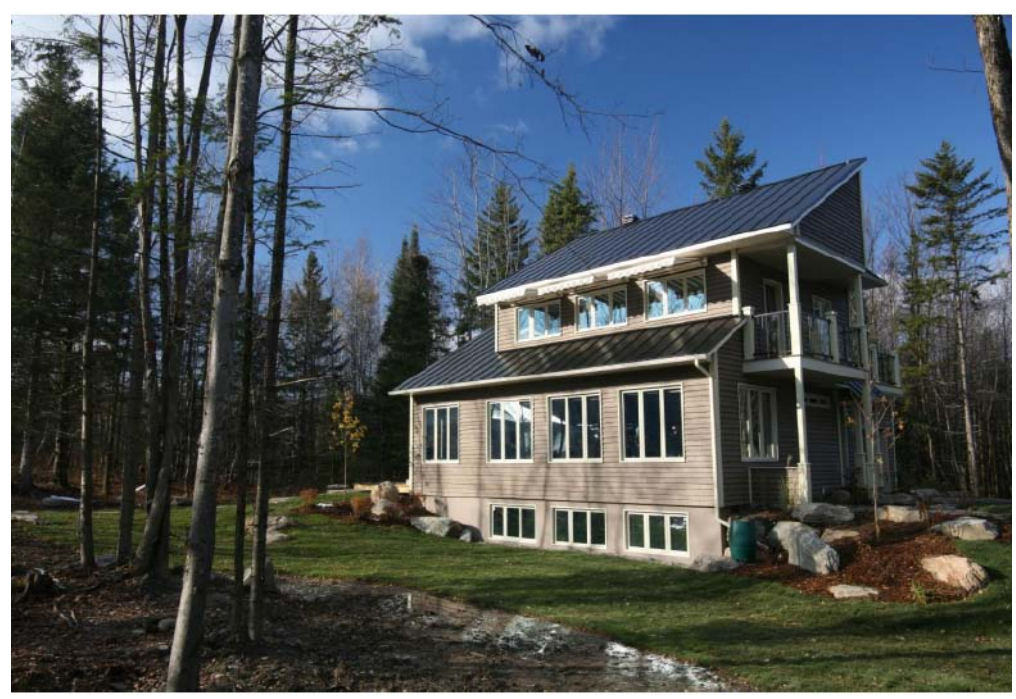

In 2006, Alouette Homes entered the house in the 'EQuilibrium' sustainable housing competition that had been run by the Canada and Mortgage and Housing Corporation (CMHC). On 13 February, 2007, CMHC unveiled the finalists of the competition. In total, 12 homebuilder teams were originally selected out of 72 entries and the Alouette Homes’ ÉcoTerra house was also included in the list of the winning projects. On 
9 November, 2007, the grand opening of the ÉcoTerra house was held at the construction site in Eastman, Quebec, where the Honorable Christian Paradis, who was the then Secretary of State, made the inaugural address and congratulated Alouette Homes on the successful completion of Canada's first near net zero energy home built and commercialised through the federal government's EQuilibrium sustainable housing initiative (CMHC, 2007).

\subsection{Tenants First Housing Co-operative}

In 2000, Tenants First Housing Co-operative was formed through the amalgamation of six separate housing cooperatives, based in Aberdeen, Scotland. The original cooperatives were set up in response to the Housing Act 1988. Today, it possesses over 1,300 properties being recognised as the largest fully mutual housing co-op in the UK. Tenants First Housing Co-operative attended the Zeroenergy Mass Custom Home Mission to Japan in 2007 and 2008. Following the success of the 2006 mission delegate's ÉcoTerra house project, it is also taking the initiative for construction of net zero carbon emission affordable homes in consideration of housing social, economic and environmental sustainability. For purpose of this aim, a three-year R\&D project was developed launched on 27 May, 2009. Since then, this $£ 1.5$ million zero carbon affordable housing project has been carried out in partnership with the Mackintosh School of Architecture, The Glasgow School of Art, and supported partially by the UK Government through the Knowledge Transfer Partnership programme. In view of the Code for Sustainable Homes scheme that sets the UK quality standard for sustainable housing developments, ten zero carbon mass custom homes will be constructed initially in Aberdeen, Scotland, by 2012. The building material and system studies had been conducted and the initial design development is currently in progress. A design workshop (i.e., 'charrette') is about to be organised so as to solidify the solution sets through interdisciplinary industry-academia discussions.

\subsection{ROBERTRYAN Homes}

ROBERTRYAN Homes is the marketing name for Ayrshire-based RDK Construction and RobertRyan Timber Engineering. RDK Construction Ltd. was founded in 1992 and today, it is recognised as one of the National House-Building Council registered builders in the UK. The company is owned by Scottish brothers, Billy and Robert Kirkwood, and both attended the Zero-carbon Mass Custom Home Mission to Japan held in 2007. Afterwards, the former became one of the ardent industry advocates of zero carbon modular homes through the Scottish Building Federation, which he was serving as the President in 2007. In 2010, ROBERTRYAN Homes unveiled their attempt to develop a net zero energy housing prototype, called 'Z-en house' (Figure 9). The research has been undertaken in partnership with the Mackintosh School of Architecture. The house will be designed to optimise passive solar gains, yet heated mechanically using energy sources, which can be characterised by low $\mathrm{CO}_{2}$ emissions. The effect of a solar PV thermal mechanical ventilation heat recovery (PV/T MVHR) system has been studied in collaboration with Prof. Mitsuhiro Udagawa, Kogakuin University, Japan. The PV/T MVHR system, which is new to the UK housing industry today, will be applied to the Z-en house for lowering energy load for heating the habitable space, whilst generating the power locally during the daytime. The construction documents of the housing prototype 
are currently reviewed by the local authority. Moreover, in order to analyse the actual building performance, the house's post occupancy evaluation (PoE) will be carried out in due course. Based on the PoE results, the current design approach to delivering the Z-en house will be retuned so as to build three subsequent homes in Scotland.

Figure 9 The Z-en house, ROBERTRYAN Homes (see online version for colours)

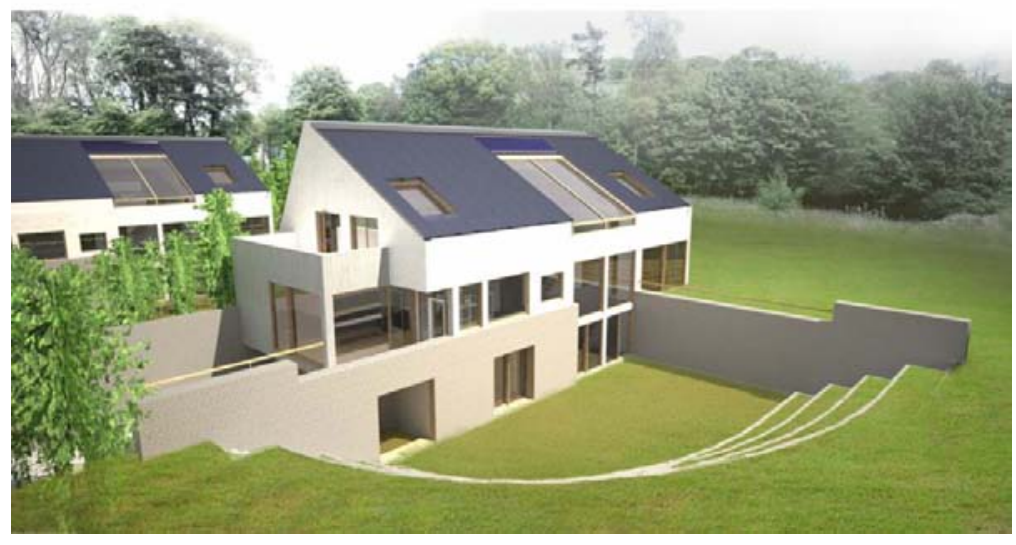

Source: MEARU Mackintosh School of Architecture

\section{Conclusions}

Today's house-builders rarely adopt (or buy) new products and services which to some degree interrupt their business operation being often based on 'routine'. Nonetheless, the application of innovative design techniques and building materials and systems including renewable energy technologies nowadays has the potential to help them deliver zero energy/carbon mass custom homes that correspond with the global market aspirations - i.e., social, economic, and environmental sustainability. Given the theoretical issues of industrial buying behaviour, homebuilders seem to be unwilling to pay for information and to restrict their information search to the 'programmed' decisions. That is because the search for information needed for the 'non-programmed' decisions of whether or not to purchase unfamiliar design and construction systems takes too much time, money and effort. Thus, to change housing suppliers' perception to the unfamiliar products and services applied for the commercialisation of zero energy/carbon mass custom homes, conventional house-builders and housing manufacturers should be given educational opportunities that help them understand not only the value of innovative design techniques, and building materials and systems, which are readily available on the market today, but also the marketability of such homes. To open the gate for them to grasp the new business opportunities, the 'Zero-energy Mass Custom Home Mission to Japan' knowledge transfer educational event was organised in 2006, 2007, 2008 and 2010. Consequently, it helped transformed three industry participants in North America and Europe from conventional housing suppliers to early adopters (or champions) of zero energy/carbon mass custom homes in their local contexts. 


\section{References}

Blythe, J. (1997) Essence of Consumer Behaviour, Prentice Hall, London.

Canada Mortgage and Housing Corporation (CMHC) (2007) EQuilibrium Healthy Housing for a Healthy Environment Project Profile: ÉcoTerraTM House - Eastman, CMHC, Quebec, Ottawa.

Ishida, K. (2008) 'The global warming prevention strategy for housing in Japan', Open House International, Vol. 33, No. 3, pp.38-47.

Japan Prefabricated Construction Suppliers and Manufacturers Association (JPA) (2008) Prefab Club, available at http://www.purekyo.or.jp/3-1.html (accessed on 13 March 2008).

Japan Prefabricated Construction Suppliers and Manufacturers Association (JPA) (2010) Prefab Club, available at http://www.purekyo.or.jp/3-1.html (accessed on 7 April 2010).

Noguchi, M. (2003) 'The effect of the quality-oriented production approach for the delivery of prefabricated housing in Japan', Journal of Housing and the Built Environment, Vol. 18, No. 4, pp.353-364.

Noguchi, M. (2008a) 'Structuring a choice model for mass customisation', International Journal of Mass Customisation, Vol. 2, Nos. 3/4, pp.264-281.

Noguchi, M. (2008b) 'Net zero-energy home design strategies learned from Canadian experience', Open House International, Vol. 33, No. 3, pp.88-95.

Noguchi, M. and Collins, D. (2008) 'Commercialisation strategies for net zero-energy-cost housing in Japan’, Open House International, Vol. 33, No. 3, pp.96-104.

Noguchi, M. and Friedman, A. (2002) 'Manufacturers-user communication in industrialised housing in Japan', Open House International, Vol. 27, No. 2, pp.21-29.

Noguchi, M. and Hadjri, K. (2009) 'Mass custom design for sustainable housing development', in Piller, F. and Tseng, M. (Ed.): Handbook of Research in Mass Customization and Personalization, Vol. 2, pp.892-910, World Scientific Publishing, London.

Noguchi, M. and Hernández, C. (2005) 'A 'mass custom design’ approach to upgrading traditional housing development in Mexico’, Journal of Habitat International, Vol. 29, No. 2, pp.325-336.

Onkvisit, S. and Shaw, J.J. (1994) Consumer Behavior: Strategy and Analysis, Macmillan, New York.

Onyango, J. and Noguchi, M. (2009) 'Changing attitudes of community through the design Charrette process', The International Journal of Neighbourhood Renewal, Vol. 1, Edition 3, pp.19-30.

Peter, J.P. and Olson, J.C. (1996) Consumer Behavior and Marketing Strategy, 4th ed., Irwin, Chicago.

Richard, R.B. and Noguchi, M. (2006) The Japan Solar Photovoltaic Manufactured Housing Technical Mission 2006, CanmetENERGY, Natural Resources Canada, Varennes.

Roberts, J. (1970) 'Home-building U.S.A.: a system analysis', Industrialization Forum, 1.3., pp.35-40.

Schiffman, L.G. and Kanuk, L.L. (1999) Consumer Behavior, 7th ed., Prentice Hall, New Jersey.

Webster, F.T. and Wind, Y. (1972) Organizational Buying Behavior, Prentice-Hall, Englewood Cliffs. 